\title{
The seed bank in Pinus stand regeneration in NW Spain after wildfire
}

\author{
L. Valbuena, R. Nuñez and L. Calvo
}

Valbuena, L., Nuñez, R. and Calvo, L. 2001. The seed bank in Pinus stand regeneration in NW Spain after wildfire. - Web Ecol. 2: 22-31.

In the Cantabrian area (northwest Spain) Pinus stands occupy many of the original shrub communities that have been considered unproductive. These Pinus stands represent the vegetation which is most affected by fire. Regeneration after fire may occur in different ways: by resprouting or by germination or both. Germination was the only regeneration mechanism in Pinus species that appeared in these areas. The aim of this study is to determine the role of the soil seed bank in regeneration in this type of ecosystem. In order to carry out the study, three communities dominated by Pinus sylvestris which had suffered wildfires were chosen. In each of the three experimental sites of Pinus sylvestris stands the seed bank composition and above-ground vegetation were studied. The results allowed three species groups in the seed bank to be differentiated: those favoured by fire, amongst which some hardseeds, mainly belonging to Cistaceae and Leguminosae, were found; another group formed by outsider or opportunist species from outside the community and which used anemochory as their main dispersion mechanism; and the third group formed by those negatively affected, amongst which were species using vegetative resprout as the main regeneration mechanism. The species of greatest quantitative importance in the seed bank was Erica australis. In general, anemochorous species were predominant in the soil seed bank. During the first stages of succession chamaephytes were dominant and in the two years after fire therophytes were. No great similarity was observed between the bank composition and field vegetation from a qualitative viewpoint, due to differences in the presence of seeds of outsider plants in the bank and to the significance of the resprouting species in the field.

L.Valbuena (degmvr@unileon.es) and L. Calvo, Area of Ecology, Fac. of Biology.Univ.of León, E-24071 Leon, Spain. - R. Nuñez, Area of Ecology, Dept of Ciencias Agroforestales, Univ. of Valladolid, Avda de Madrid, E-34004 Palencia, Spain.

Fire can be considered as an ecological component of the Mediterranean ecosystems. In the Mediterranean region, conifer forests, especially pine forests (Quezel 1980), are well known for their vulnerability to fire. Because of their dense linear structure and the characteristics of the species used in reforestation, reforested sites of pines tend to undergo intense fires which very often prevent the survival of vegetation. Many of these species of pines - Pinus halepensis Miller, Pinus brutia Ten. (Thanos and Marcou 1991), for example, are favoured by fire and the forest becomes more extended. Other species, like Pinus nigra Arnold are not so favoured as they can regenerate easily and naturally in the absence of fire and in special environmental conditions (Trabaud and Campant 1991). Scots pine Pinus sylvestris $\mathrm{L}$. is one of the most important species in the Spanish forest covering ca 900000 ha with ca 50\% 
being planted in the 20 century. In the northwest of the Iberian Peninsula (Castilla and León region) the Scots pine forest is one of those most affected by fire. From 1988 to 1996 the total surface of Scots pine burned was 16928 ha, (Del Hierro pers. comm.)

Seedling recruitment occurs mainly in the period immediately after fire, although a significant amount can also occur later in the inter-fire period (Purdie 1977). The spectacular pulse of seedling recruitment that may follow fire is the result of a disturbance in established vegetation cover and the formation of openings generally required for successful recruitment in plants (White 1979), and also from the dormancy-breaking effect of fire on accumulated seed banks. Three primary strategies were recognised by Naveh (1975) in species regrowing after fire: obligate seed regeneration (recovery by seedlings only), facultative resprouting (recovery by seedlings and resprouts), and obligate resprouting (recovery by resprouts only). This type of stand is usually comprised of a mixture of species exhibiting these three primary regeneration strategies. The role of outsider species, which can colonise the burned sites through their anemochorous seeds from areas close by, also has to be stressed.

Species contributing to successional changes can either be present in the initial aboveground vegetation (Egler 1954), in the seed bank or in the seed rain. Viable seeds have long been known to persist in the soil for many years (Jensen 1998). The relation between seed bank and aboveground vegetation and the impact of the seed bank on progressive and regressive succession remains unclear.

The aims of the present study were 1) to investigate the species composition of the seed bank of Scots pine stands, 2) to examine the relationship between the seed bank and aboveground vegetation in the successional series after fire and 3) to discuss the possible importance of the seed bank in the succession process and the changes of the seed bank in time after fire.

\section{Materials and methods}

\section{Study sites}

The study was carried out in northwest Spain. Three study sites were selected, two of them in the province of León and the third in the province of Palencia. The three sites were in Pinus sylvestris L. stands which had undergone wildfires.

\section{Site A}

This site was situated in the north of the province of Léon at an altitude of $1025 \mathrm{~m}$. It has a $30 \%$ gradient and faces northeast. The geographical co-ordinates are $42^{\circ} 43^{\prime} \mathrm{N}-$ $5^{\circ} 02^{\prime} \mathrm{W}$. It was a regenerated pine stand of 5-yr-old Pinus sylvestris which was burnt on 21 August 1994, during an intense surface fire. The mean annual temperature is $10.3^{\circ} \mathrm{C}$ with $629 \mathrm{~mm}$ average annual rainfall. Drought occurs in July and August. The soil has moderate acidity $(\mathrm{pH}=5.6)$, lacking carbonates, franco-sandy texture, $1.9 \%$ organic material, $1 \mathrm{ppm}$ phosphorous, $70 \mathrm{ppm}$ potassium, and $2.5 \mathrm{meq} / 100 \mathrm{~g}$ calcium.

\section{Site B}

Situated in northern Palencia at $1130 \mathrm{~m}$. It is exposed to all winds and its co-ordinates are $42^{\circ} 42^{\prime} 43^{\prime} \mathrm{N}-4^{\circ} 46^{\prime} 10^{\prime} \mathrm{W}$. The site contained a pine stand reforested by $30-40$ yr-old Pinus sylvestris burnt on 13 June 1994. In this case it was an intense surface fire which did not cause much damage to the tree crowns. The mean annual temperature is $8.8^{\circ} \mathrm{C}$, mean annual rainfall $686.4 \mathrm{~mm}$. The soil has a moderate acidity $(\mathrm{pH}=5.5)$, very slightly saturated bases $(16 \%)$, no carbonates, franco-sandy texture, $1.5 \%$ organic material, 2 ppm phosphorous, $55 \mathrm{ppm}$ potassium and $1.2 \mathrm{meq} / 100 \mathrm{~g}$ calcium.

\section{Site $C$}

Situated in the north of the province of Léon at $1020 \mathrm{~m}$ with a $10 \%$ gradient facing northeast. Its co-ordinates are $42^{\circ} 40^{\prime} 28^{\prime} \mathrm{N}-5^{\circ} 05^{\prime} \mathrm{W}$. The site contained a pine stand reforested by $20 \mathrm{yr}$-old Pinus sylvestris which was burnt on 27 March 1997, by an extremely intense fire which seriously damaged the tree crowns. The mean annual temperature is $10.9^{\circ} \mathrm{C}$ and mean annual rainfall is $926.7 \mathrm{~mm}$.

According to the Allue classification (1991) the three sites are class IV (VI) subhumid Mediterranean with a central European tendency. The soil is humic Cambisol (Anon. 1970) with similar characteristics at the three sites.

The three sites consisted of the same type of plant community, with the aboveground stratum dominated by $P i$ nus sylvestris and the understorey by Erica australis L., Genistella tridentata L., Calluna vulgaris (L.) Hull and Halimium alyssoides (Lam.) C. Koch. These sites had been affected by surface fires, which had produced similar effects in the undergrowth, although there were slight differences in the trees as regards the percentage of dead ones.

\section{Seed bank determination}

In this study the seed bank was determined by the indirect technique, consisting of collecting soil samples and recording the seedlings that appeared. The seedling emergence technique can underestimate the numbers of seeds present, but viable seeds are able to germinate. Despite this limitation, Thompson et al. (1997) state that the indirect method is desirable and appropriate for community level studies.

Ten sampling units $(20 \times 25 \mathrm{~cm}$ each and $5 \mathrm{~cm}$ deep $)$ were chosen in sites A and B in each burned area and 10 
sampling units in each control area (non-burned site). The samplings were carried out immediately after (situation 0 yr), 1 and $2 \mathrm{yr}$ after the fire ( $1 \mathrm{yr}$ and $2 \mathrm{yr}$ ). In site C, 12 sample units $(20 \times 25 \mathrm{~cm}$ and $5 \mathrm{~cm}$ deep) were chosen for only immediately after the fire (situation 0 ). The samplings were randomly performed at least $10 \mathrm{~m}$ from the burnt border and at least $2 \mathrm{~m}$ apart.

The soil samples were laid out in trays in a greenhouse. As the aim of the study was to know and study the soil seed bank, all roots and bulbs or tubercles were discarded to avoid any plants coming from sprouts. The soil layers were spread out on the trays on two thick sheets of filter paper to avoid any leaching of the loam or loss of seeds. The thickness of the soil layer on the trays was $2 \mathrm{~cm}$. The temperature in the greenhouse was kept at $14-24^{\circ} \mathrm{C}$ during the study. Environmental conditions consisted of natural photoperiods and watering regularly every day with tap water. Greenhouse relative humidity was kept at $40-70 \%$ throughout the study period; $100 \%$ humidity was reached when the trays were watered by automatic spraying. Every week the germinated seedlings were identified and counted. Follow-up was carried out over 15 months for each period of time studied: immediately after the fire, one year and two years later. No attempt was made to test the viability of community seeds using tetrazolium because they were too small $(<1 \mathrm{~mm})$.

\section{Field observations}

The direct or diachronic method (Pavillard 1935) was chosen to study vegetation recovery after the fire. This meant studying the modifications in vegetation over time in permanent plots marked out post-fire.

In order to carry out the aboveground vegetation study in each study area (A, B and C), three transects measuring $25 \times 1 \mathrm{~m}$ were established. These transects were fixed to carry out the later controls in time. The transects were beside the areas from which the soil samples for the seed bank study were taken. Twenty-five sampling units measuring 1 $\mathrm{m}^{2}$ each were studied in each transect. The percent cover in vertical projection of all the species (woody, annuals herbaceous and perennials herbaceous) were evaluated for each sampling unit. The dates for carrying out the samplings were: immediately after the fire, after one year in areas A, B and $\mathrm{C}$, and after two years in areas A and B. These dates coincide with the soil samples for the seed bank study except for area $\mathrm{C}$, where no seed bank samples were taken after one year.

Life forms of adult plants were characterised according to the Raunkiaer system (1905) and dispersal types were identified using the Molinier and Muller (1938), Van der Pijl (1969) and Murray (1986) classifications.

Plant nomenclature was according to Tutin et al. 19641980.

\section{Data Analysis}

The three study sites (A, B and C) were considered as three replicate Pinus sylvestris pine stands, as the communities were the same and the effect of fire on the understorey too. Statistical treatment of the seed bank was based on seed density data for each species per square metre, with the aim of comparing all the study sites. The data in Table 1 show the mean values and the standard error of the number of seeds per square meter, for each species in the three areas.

Data of percentage cover in vertical projection were used to carry out the statistical treatment of aboveground vegetation. The data in Table 2 show the mean cover values and the standard error of the species present in the three areas.

The relation between seed bank and aboveground vegetation of the permanent plots was determined using qualitative percent disagreement and unweighted pair-group average as a linkage rule. This analysis was carried out using the STATISTICA (Anon. 1995) statistics package.

\section{Results}

\section{Seed bank}

The mean post fire density of the seed bank, immediately after the fire (Table 1), was 537 seeds $\mathrm{m}^{-2}$, slightly less than that of the seed bank control ( 708 seeds $\left.\mathrm{m}^{-2}\right)$, although the differences in the latter case amongst the sites were much more apparent. During the first year there was a significant increase in the number of seeds in the bank $\left(908\right.$ seeds $\mathrm{m}^{-}$ ${ }^{2}$ ), which exceeded the control. The species with greater representation, both in the control seed bank and the burned one (immediately after the fire and after one year) was Erica australis.

In terms of the effect of fire on germination the following could be differentiated: first, a group of species which benefited, as they only appeared immediately after the fire and not in the control bank, Leguminosae: Genistella tridentata, Lotus corniculatus L., and Trifolium sp.; Gramineae Aira caryophyllea L.; Caryophyllaceae: Arenaria montana L. These Leguminosae species are hardseeds, but Arenaria montana is a permeable testa species and we have not been possible to characterise the testa type of Aira caryophyllea. A second group of species could be defined as colonisers or invaders since they only appeared after 1 or $2 \mathrm{yr}$ and not in the control situation: Fam. Compositae: Conyza canadensis L. Cronk., Senecio vulgaris L. and Sonchus asper (L.) Hill, all of them with anemochory dispersion. The group negatively affected by fire, as they were present in the control and not after fire, consisted of Capsella bursa-pastoris L. Medicus and Taraxacum officinale Weber. Finally, the species present both in the control situation and after the fire were: Avenula marginata (Lowe) J. Holub; Bromus sterilis L., Daucus sp., Erica australis, Festuca ovina L., Halimium 
Table 1 . Mean density $\pm S E$ of the seeds present in the soil seed bank in the control situation and in time after fire $(0,1,2 \mathrm{yr})$ of the three sites (A, B and C). Traits: $\mathrm{H}=$ Herbaceous species, $\mathrm{P}=$ Perennial species, $\mathrm{A}=$ annual species, $\mathrm{BA}=$ biannual species, $\mathrm{W}=\mathrm{Woody}$ species. Life forms: $\mathrm{H}=$ Hemicryptophyte, $\mathrm{T}=$ Therophyte, $\mathrm{C}=$ Chamaephyte. Regeneration strategies: $\mathrm{S}=$ Seeders, $\mathrm{R}=\mathrm{Resprout}, \mathrm{S} / \mathrm{R}=$ Seeders and resprouters. Seed dispersion types: $\mathrm{An}=$ Anemochory, $\mathrm{Au}=$ Autochory, $\mathrm{E}=$ Epizoochory, $\mathrm{B}=\mathrm{Barochory}$ and $\mathrm{Z}=$ Zoochory.

\begin{tabular}{|c|c|c|c|c|c|c|c|c|}
\hline & \multirow[b]{2}{*}{ Control } & \multicolumn{3}{|c|}{ Years after fire } & \multirow[b]{2}{*}{ Traits } & \multirow[b]{2}{*}{$\begin{array}{l}\text { Life } \\
\text { forms }\end{array}$} & \multirow[b]{2}{*}{$\begin{array}{l}\text { Regeneration } \\
\text { strategies }\end{array}$} & \multirow[b]{2}{*}{$\begin{array}{l}\text { Seed } \\
\text { dispersal }\end{array}$} \\
\hline & & $0 \mathrm{yr}$ & $1 \mathrm{yr}$ & $2 \mathrm{yr}$ & & & & \\
\hline Total & $708 \pm 508$ & $537 \pm 135$ & $908 \pm 136$ & $340 \pm 64$ & & & & \\
\hline \multicolumn{9}{|l|}{ F. Caryophyllaceae } \\
\hline $\begin{array}{l}\text { Arenaria montana } \\
\text { F. Cruciferae }\end{array}$ & 0 & $6 \pm 1$ & 0 & 0 & $\mathrm{P}, \mathrm{H}$ & $\mathrm{C}$ & $S(R)$ & $\mathrm{Au}$ \\
\hline $\begin{array}{l}\text { Arabidopsis thaliana } \\
\text { F. Leguminoseae }\end{array}$ & 0 & 0 & 0 & $6 \pm 6$ & A, $\mathrm{H}$ & $\mathrm{T}$ & $S$ & $\mathrm{Au}$ \\
\hline Anthyllis vulneraria & 0 & $9 \pm 7$ & $254 \pm 254$ & 0 & $\mathrm{P}, \mathrm{H}$ & $\mathrm{H}$ & $S$ & An \\
\hline Genistella tridentata & 0 & $32 \pm 32$ & 0 & 0 & P, W & $\mathrm{C}$ & $\mathrm{R}$ & $\mathrm{Au}$ \\
\hline Lotus corniculatus & 0 & $20 \pm 6$ & 0 & 0 & $\mathrm{P}, \mathrm{H}$ & $\mathrm{H}$ & $S$ & $\mathrm{~B}$ \\
\hline Trifolium sp. & 0 & $2 \pm 2$ & 0 & 0 & A, $\mathrm{H}$ & $\mathrm{T}$ & $S$ & An, $Z$ \\
\hline \multicolumn{9}{|l|}{ F. Cistaceae } \\
\hline Halimium alyssoides & $26 \pm 22$ & $113 \pm 33$ & $18 \pm 2$ & $18 \pm 6$ & $\mathrm{P}, \mathrm{W}$ & $\mathrm{C}$ & $S(\mathrm{R})$ & $\mathrm{Au}$ \\
\hline $\begin{array}{l}\text { Halimium umbellatum } \\
\text { F. Chenopodiaceae }\end{array}$ & $6 \pm 6$ & $67 \pm 63$ & 0 & 0 & P, W & $\mathrm{C}$ & $\mathrm{R} / \mathrm{S}$ & $\mathrm{Au}$ \\
\hline Chenopodium album & 0 & 0 & 0 & $2 \pm 2$ & $\mathrm{~A}, \mathrm{H}$ & $\mathrm{T}$ & S & \\
\hline \multicolumn{9}{|l|}{ F. Brasicaceae } \\
\hline Sisymbrium sp. & 0 & 0 & 0 & $2 \pm 2$ & A, P, H & $\mathrm{H}, \mathrm{T}$ & S & $\begin{array}{l}\mathrm{Au} \\
\mathrm{Au}\end{array}$ \\
\hline \multicolumn{9}{|l|}{ F. Umbelliferae } \\
\hline $\begin{array}{l}\text { Daucussp. } \\
\text { F. Ericaceae }\end{array}$ & $4 \pm 4$ & 0 & $86 \pm 86$ & 0 & $\mathrm{BA}, \mathrm{H}$ & $\mathrm{H}$ & $S$ & $\mathrm{E}$ \\
\hline Erica australis & $486 \pm 312$ & $206 \pm 75$ & $294 \pm 110$ & $30 \pm 2$ & $\mathrm{P}, \mathrm{W}$ & $\mathrm{C}$ & $\mathrm{R}(\mathrm{S})$ & An \\
\hline \multicolumn{9}{|l|}{ F. Compositae } \\
\hline Senecio vulgaris & 0 & 0 & $24 \pm 0$ & $6 \pm 2$ & $\mathrm{~A}, \mathrm{H}$ & $\mathrm{T}$ & $\begin{array}{l}S \\
S\end{array}$ & $\begin{array}{l}\text { An } \\
\text { An }\end{array}$ \\
\hline Taraxacum officinale & $2 \pm 2$ & 0 & 0 & 0 & $\mathrm{P}, \mathrm{H}$ & $\mathrm{H}$ & S & An \\
\hline Sonchus asper & 0 & 0 & $2 \pm 2$ & $44 \pm 24$ & $\mathrm{~A}, \mathrm{H}$ & $\mathrm{T}$ & $S$ & An \\
\hline \multicolumn{9}{|l|}{ F. Gramineae } \\
\hline Aira caryophyllea & 0 & $37 \pm 37$ & 0 & 0 & & & & \\
\hline Avenula marginata & $10 \pm 10$ & $5 \pm 2$ & 0 & 0 & $\mathrm{P}, \mathrm{H}$ & $\mathrm{H}$ & $\mathrm{R}$ & An \\
\hline Bromus sterilis & $150 \pm 150$ & $3 \pm 3$ & $12 \pm 12$ & 0 & $\mathrm{P}, \mathrm{H}$ & $\mathrm{H}$ & & An \\
\hline Festuca ovina & $10 \pm 10$ & $1 \pm 1$ & $0 \pm 0$ & 0 & $\mathrm{P}, \mathrm{H}$ & $\mathrm{H}$ & & An \\
\hline Others Gramineae & $8 \pm 4$ & $27 \pm 5$ & $20 \pm 0$ & $58 \pm 38$ & $\mathrm{P}, \mathrm{H}$ & $\mathrm{H}$ & & An \\
\hline Others & $20 \pm 4$ & $9 \pm 5$ & $20 \pm 8$ & $52 \pm 8$ & & & & \\
\hline
\end{tabular}

alyssoides, Halimium umbellatum (L.) Spach. The last two benefited quantitatively from fire.

One year later, the seed bank reached its maximum values mainly due to the presence of Anthyllis vulneraria L. and Erica australis.

The germination of certain species was favoured immediately after fire and so specific richness increased, but decreased in time. In the second year after the fire, both richness and density decreased.

\section{Field vegetation}

The species characterising these pine communities and present in the control situation with high cover values were (Table 2): Pinus sylvestris, Quercus pyrenaica Willd, Erica australis, Genistella tridentata, Halimium alyssoides and Agrostis capillaris L. The woody species were dominant in these communities.

Shortly after the fire and coinciding with collection from the seed bank, the species present in the field (Table 
2) were: Erica australis (1.34\%), Genistella tridentata (0.85\%), Halimium alyssoides (0.33\%), Quercus pyrenaica $(0.14 \%)$, Avenula marginata (1.48\%), and Luzula lactea $(1.36 \%)$ Link ex E.H.F. Meyer. All of them had very low cover values. The majority of these species appeared from resprouting and at one of the sites (Site C), Halimium alyssoides appeared from seeds. The main herbaceous species appearing were perennial. These species presented protection mechanisms, such as basal rosettes, against fires.

The mainly resprouting woody species, like Erica australis and Genistella tridentata, increased their cover values in time. In the same way the typically germinating species Pinus sylvestris, Halimium alyssoides and Halimium umbellatum appeared during the first year after fire. The persistence of the woody resprouting species and the appearance of obligate seeder species caused an increase in specific richness during the first year.

\section{Characterisation of seed bank and field vegetation}

\section{Seed bank}

Twelve, of the total 21 species determined in the soil seed bank, are corresponded to obligate seeder as a regeneration strategy (Table 1). However, the species with the greatest density per $\mathrm{m}^{2}$ in the control situation and immediately after the fire were those capable of both resprouting and germinating (Fig. 1b), such as Erica australis, Genistella tridentata, Halimium alyssoides and Halimium umbellatum. The obligate seeders became dominant in both richness and density from the first year onwards.

Species with anemochory (Fig. 1c) were clearly dominant throughout the study period in the control situation as well as after the fire. An increase in the density of species with autochory dispersion was also observed in the postfire situation, due to the beneficial effect of the high temperatures on Halimium alyssoides and Halimium umbellatum germination.

In relation to life forms (Fig. 1a), chamaephytes were dominant in the control situation and straight after the fire. In the first year, both chamaephytes and hemicryptophytes presented the highest densities and in the second year, the therophytes did. This was a foreseeable situation as the bank became less viable and the annual herbaceous species began their contribution.

\section{Field vegetation}

As in the case of the seed bank, chamaephytes clearly dominated in field vegetation throughout the study period (Fig. 2a) whilst hemicryptophytes became more important in the later years. Autochory and anemochory were the most common forms of dispersion.

All three types $(S, R, S / R)$ presented equivalent amounts as far as regeneration was concerned (Fig. 2b) and

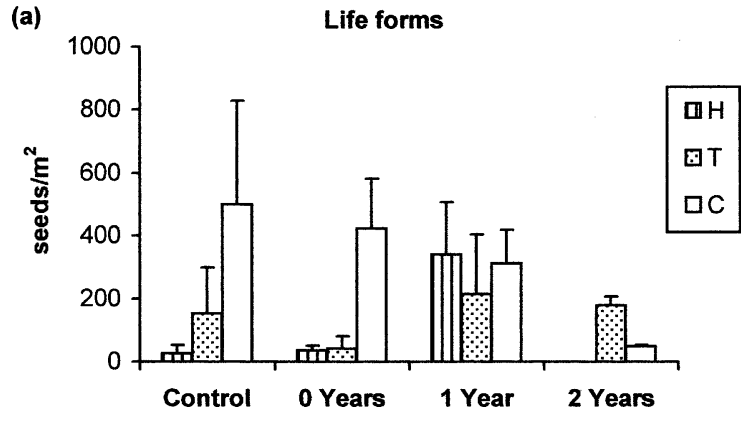

(b) Regeneration strategies
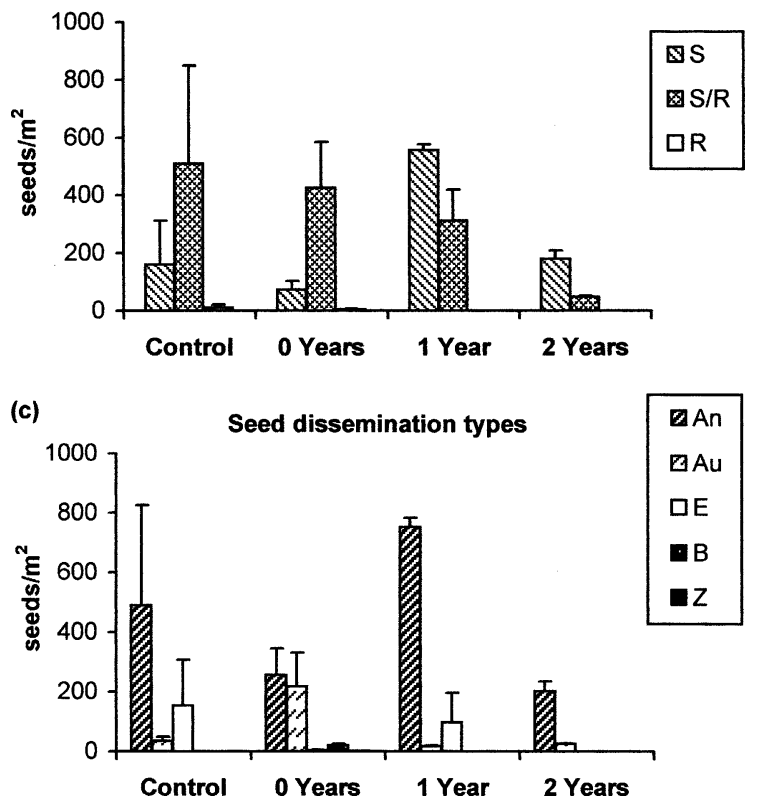

Fig. 1. Mean number of seeds per $\mathrm{m}^{2}$ and SE of traits of species present in the soil seed bank in the control situation and in time after fire (0, 1, 2 yr). Life forms (a): $\mathrm{H}=$ Hemicryptophyte, $\mathrm{T}=$ Therophyte, $\mathrm{C}=$ Chamaephyte. Regeneration strategies (b): $\mathrm{S}=$ Seeders, $\mathrm{R}=$ Resprout, $\mathrm{S} / \mathrm{R}=$ Seeders and resprouters. Seed dispersion types $(\mathrm{c}): \mathrm{An}=$ Anemochory, $\mathrm{Au}=$ Autochory, $\mathrm{E}=$ Epizoochory, $\mathrm{B}=$ Barochory and $\mathrm{Z}=$ Zoochory.

were maintained for one year after the fire. Two years after the fire the species with vegetative resprout regeneration and with both mechanisms had the highest cover values (Fig. 2c).

\section{Relation between seed bank and aboveground vegetation}

In the qualitative analysis of percent disagreement (Fig. 3) we observed the formation of two clearly differentiated groups. One of them was formed by all the seed bank samplings and the aboveground vegetation appearing immediately after the fire (F-0); although the link with the latter showed the least similarity. This group was formed 


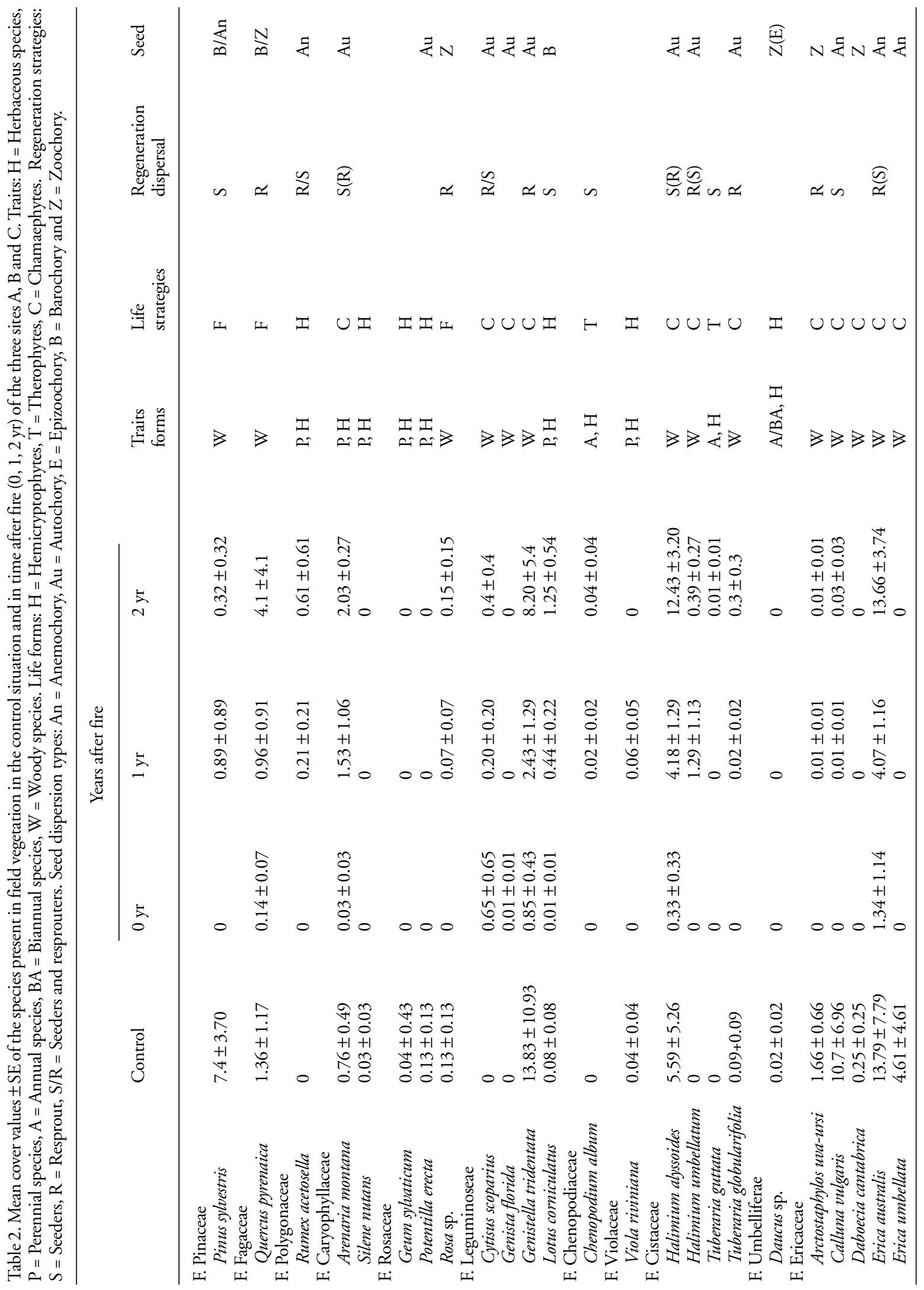




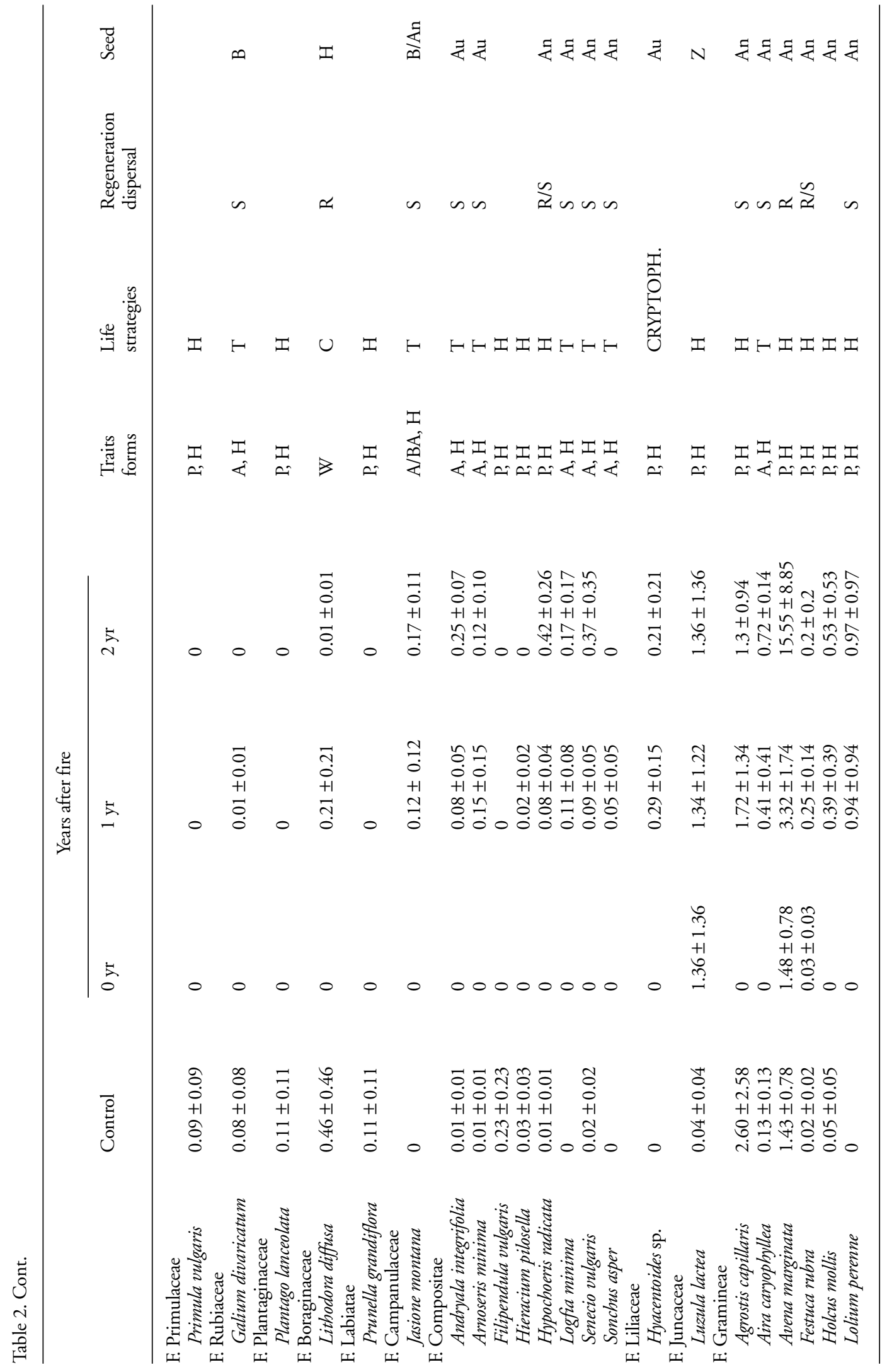


(a)

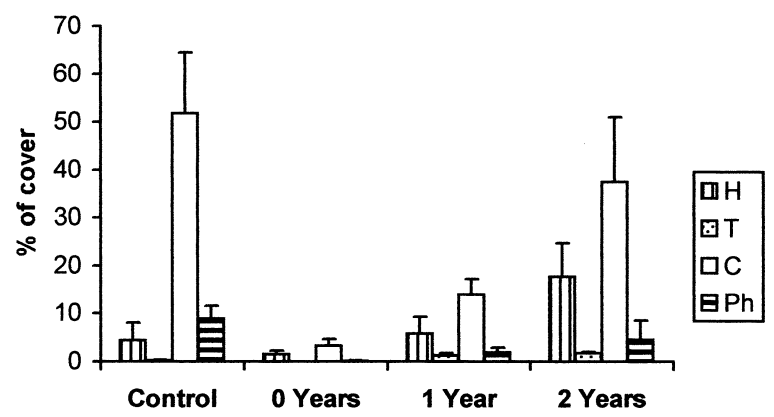

(b)

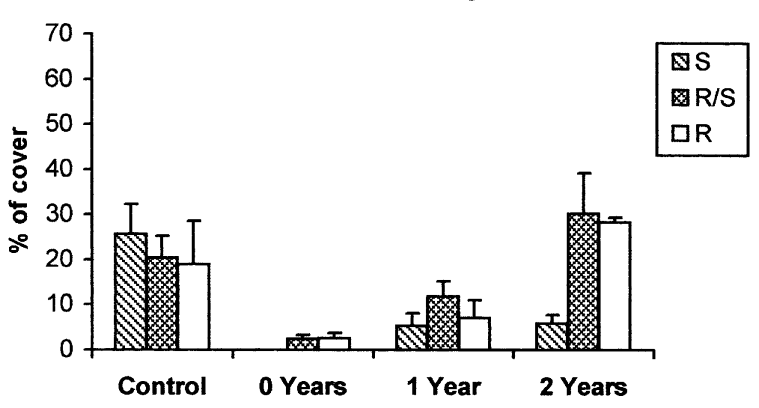

(c)

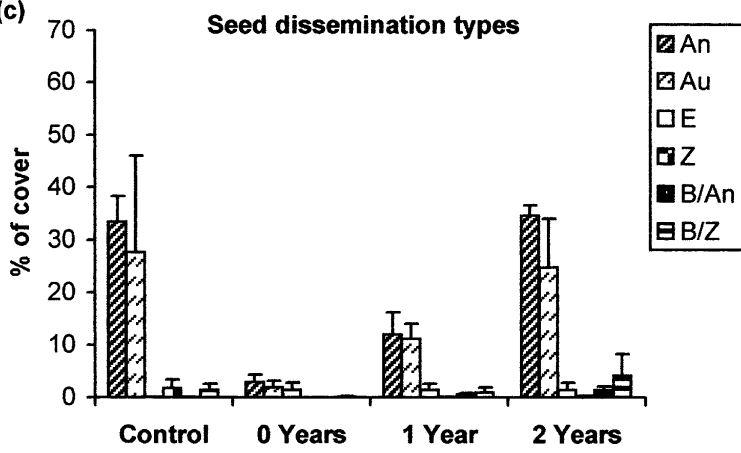

Fig. 2. Mean percentage of cover and SE of traits of species present in the aboveground vegetation in the control situation and in time after fire (0, 1, 2 yr). Life forms (a): $\mathrm{H}=$ Hemicryptophytes, $\mathrm{T}=$ Therophytes, $\mathrm{C}=$ Chamaephytes, $\mathrm{Ph}=$ Phanerophytes. Regeneration strategies (b): $\mathrm{S}=$ Seeders, $\mathrm{R}=$ Resprouters, $\mathrm{S} / \mathrm{R}=$ Seeders and resprouters. Seed dispersion types (c): An = Anemochory, $\mathrm{Au}=$ Autochory, $\mathrm{E}=$ Epizoochory, $\mathrm{B}=$ Barochory, $\mathrm{Z}=$ Zoochory.

due to the absence of species like Arnoseris minima, Calluna vulgaris, Holcus mollis, Hypochoeris radicata, Lithodora diffusa, Pinus sylvestris and Rosa sp. which were present in the aboveground vegetation samplings in both the control situation and 1,2 yr after fire. The greatest similarity was between the seed bank samplings in the control situation and immediately after the fire due to the presence of species belonging to the Gramineae and

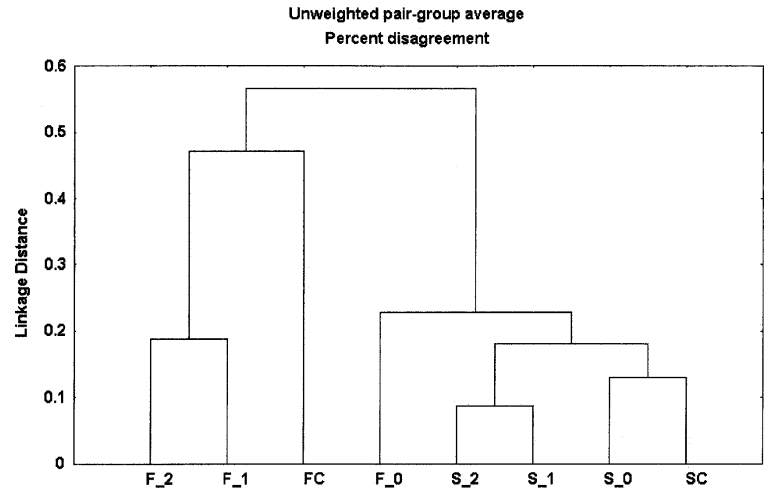

Fig. 3. Tree diagram representing the percent disagreement as linkage distance of the mean of presence-absence species in the three sites (A, B and C), in the field vegetation $(\mathrm{F})$ and in the soil seed bank $(S) . C=$ control situation; $0,1,2=y r$ after fire.

Cistaceae families. Another group with great similarity was that formed by seed bank samplings 1 and $2 \mathrm{yr}$ after fire, basically due to the presence of species belonging to the Compositae family.

In general there was no strong relationship regarding specific composition of the bank and the field. However, both aboveground vegetation and seed bank separately showed similarity between the species appearing after 1 and $2 \mathrm{yr}$.

\section{Discussion}

In the global analysis of the seed bank, the fire had a negative effect on the seed bank when the seed density in the control situation was compared to that of seeds germinated immediately after fire. This was due to the fact that one of the most representative species in both the field and seed bank, Erica australis, has seeds which are not favoured by the high temperatures and are even damaged in some cases, as demonstrated by the various germination trials carried out in the laboratory (Valbuena unpubl.). In contrast, one year after the fire there is a marked increase in total seed density in comparison with the control situation. This is due to the presence of some species considered as invaders: Conyza canadensis (Csontos et al. 1996) and Anthyllis vulneraria, whose germination is favoured by fire. After two years most of the seeds have germinated and therefore density in the bank decreased to a great degree.

When studying the response to fire of the individual species present in the seed bank, three groups could be differentiated. In the first place, many of the species that are favoured by fire, such as Cistaceae and Leguminosae. Seeds of both groups have a hard testa and so fire favours rupture and promotes germination. Laboratory trials have shown this beneficial effect of increased temperature on the germination of some of these species (Tarrega et al. 1992, Val- 
buena et al. 1994). The same beneficial effect has been seen in leguminous species (Lotus corniculatus and Trifolium sp.) which appeared immediately after a fire (Martínez Sánchez 1994 ) in field trials carried out on similar communities.

Another group of species is formed by invaders (e.g. Conyza canadensis) whose establishment is favoured by the existence of open ground and the availability of nutrients in the soil. Although these species are aliens to the community they become of high quantitative importance during the first year post-fire.

The last group is formed by those species damaged by fire, e.g., those whose abundance decrease in the soil bank after the fire, such as Erica australis and the gramineae $A v$ enula marginata, Bromus sterilis and Festuca ovina.

The specific richness of the seed bank is mainly made up of obligate seeders. Moore (1980) pointed out that seed banks usually contain a high proportion of initial successional condition species, closer to the "r" strategy, which depend on high seed longevity and are obligate seeders. However, analysis of the seed density in this type of bank shows that this dominant situation of the obligate seeders only appear one year after the fire when density is at a maximum. But in the original situation and immediately after the fire the species using both types of regeneration (resprout and germination) predominate. This coincides with the characteristics of aboveground vegetation.

The chamaephytes are clearly dominant in the seed bank immediately after the fire, as they are usually in undergrowth vegetation. As the seeds from chamaephytes disappear in the seed bank and have not had enough time in the field to regenerate and produce new seeds, the hemicryptophytes and therophytes become dominant. So, during the first year the hemicryptophytes, amongst which Anthyllis vulneraria stand out, are predominant in the seed bank. This species does not appear in the aboveground vegetation. That may be due to its seeds, as happens with other leguminosae, which allows the formation of large seed banks in the soil (Trabaud et al. 1997) and which only germinate under optimum laboratory conditions. The maximum germination rate of Anthyllis vulneraria seeds does not occur immediately after the fire but one year later as the testa could have been slightly damaged during the thermal shock of the fire and needs time to germinate. The abundance of the gramineae contribute to the high density value of the hemicryptophytes, some of which are present in the above-ground vegetation (e.g. Avenula marginata). Another hemicryptophyte with relatively high abundance values and present in above-ground vegetation is Daucus sp. The therophytes present high densities in the seed bank during the first year and become dominant during the second. Their annual production determine the incorporation of new seeds in the seed bank from the first year. This effect of the increase of therophytes in the bank is also seen in the aboveground vegetation and, as shown also by Casal (1987), Trabaud (1991) and Calvo et al. (1998a), the highest cover values appear in the first two years after the fire.
The dominant phanerophyte in these communities, $\mathrm{Pi}$ nus sylvestris, is not to be found in the seed bank as their cover percentages are very low in field vegetation (Table 2). It is not generally easy to detect their presence in the seed bank using the indirect method.

The existence of greater species richness in the aboveground vegetation than in the bank generally mean great diversification of the dispersion types used, though a clear dominance of anemochorous dispersion was observed, coinciding with the seed bank.

The effect of fire on these plantations of Pinus sylvestris is similar to that on shrub communities dominated by Erica australis. This is due to the fact that these conifers were planted on what were originally shrub communities. So when the pine stand is adult the development of the undergrowth is shrub and the arboreal community response to a disturbance is very similar to that of shrubs. Resprouting woody species like Erica australis and Quercus pyrenaica often appear as dominant in above-ground vegetation.

These results were also obtained in studies carried out on shrub communities in the northern Iberian Peninsula (Calvo 1993, Calvo et al. 1998b). The root system of these species remains intact and therefore they immediately benefit from the incorporation of nutrients from the ground. Herbaceous species are not well represented in the original situation of these communities because the woody species compete for light and also because of the possible allelopathic effect of certain woody species, as in the case of the Ericaceae (Carballeira and Cuervo 1980, Mallik 1998). Once the woody species are eliminated after a fire, there is a slight increase in the herbaceous ones in the first and second year after fire.

In conclusion there is no great qualitative similarity between the composition of the bank and the field vegetation. This could be due not only to differences in the presence of invader plant seeds but also to the fact that some resprouting species, whose seeds are not usually detected in indirect studies of the bank (Trabaud 1992, Calvo et al. 1999), are very importance in the field. From the quantitative viewpoint the dominance of Erica australis and Halimium alyssoides has to be stressed in both cases.

The importance of the seed bank in secondary succession processes after fires is demonstrated as a source of herbaceous species during the first recovery stages. The contribution of annuals amongst these herbaceous species during the first two years also needs to be emphasised.

Acknowledgements - We would like to thank Isabel Alonso for providing valuable comments on the manuscript and for revising the paper. 


\section{References}

Allue, J. L. 1991. Atlas fitoclimático de España. INIA. - Ministerio de Agricultura, Pesca y Alimentación, Madrid

Anon. 1970. Key to soil units for the soil map of the world, soil resources, development and conservation service. - F.A.O., Rome.

Anon. 1995. STATISTICA for windows. - StatSoft, Tulsa, Oklahoma.

Calvo, L. 1993. Regeneración vegetal en comunidades de Quercus pyrenaica Willd. después de incendios forestales. Análisis especial de comunidades de matorral. - Ph.D. thesis, Univ. de León, Spain.

Calvo, L., Tárrega, R. and Luis, E. 1998a. Twelve years of vegetation changes after fire in an Erica australis community. - In: Trabaud, L. (ed.), Fire management and landscape ecology. Int. Assoc. of Wildland fire, Fairfield, USA, pp. 123-136.

Calvo, L., Tarrega, R. and Luis, E. 1998b. Space-time distribution patterns of Erica australis L. subsp. aragonensis (Willk) after experimental burning, cutting, and ploughing. - Plant Ecol. 137: 1-12.

Calvo, L., Herrero, B. and Bravo, F. 1999. The influence of fire on the seed bank in the soil of Quercus faginea forest (NW Spain). - Ann. For. Sci. 56: 249-258.

Carballeira, A. and Cuervo, A. 1980. Seasonal variation in allelopathic potential of soils from Erica australis L. heathland. Oecol. Plant. 1: 335-344.

Casal, M. 1987. Post-fire dynamics of shrublands dominated by Papilionacea plants. Influence of fire on the stability of Mediterranean forest ecosystems. - Ecol. Mediterránea XIII: 8798.

Csontos, P. et al. 1996. Seed bank of Pinus nigra plantations in dolomite rock grassland habitats, and its implications for restoring grassland vegetation. - Ann. Hist. Nat. Mus. Nat. Hung. 88: 69-77.

Egler, F. E. 1954. Vegetation science concepts. I: initial floristic composition, a factor in old-field vegetation development. Vegetatio 4: 412-417.

Jensen, K. 1998. Species composition of soil seed bank and seed rain abandoned wet meadows and their relation to aboveground vegetation. - Flora 193: 345-359.

Mallik, A. U. 1998. Allelophathy and competition in coniferous forest. - In: Sassa, K. (ed.), Proc. of the IUFRO Div. 8 Conf. Environ. For. Sci., pp. 309-315.

Martínez Sánchez, J. J. 1994. Dinámica de la vegetación postincendio en la provincia de Albacete y zonas limítrofes de la provincia de Murcia. - Ph.D. thesis, Univ. of Murcia.

Molinier, R. and Muller, P. 1938. La dissémination des espèces végétales. - Rev. Gén. Bot. 50: 1-178.
Moore, P. D. 1980. Soil seed bank. - Nature 284: 123-124.

Murray, D. R. 1986. Seed dispersal. - Academic Press.

Naveh, Z. 1975. The evolutionary significance of fire in the Mediterranean region. - Vegetatio 29: 199-208.

Pavillard, J. 1935. Eléments de sociologie végétale. - Actualités Scientifiques et Industrielles, Herman et Cie, Paris.

Purdie, R. W. 1977. Early stages of regeneration after burning in dry sclerophyll vegetation. II Regeneration by seed germination. - Aust. J. Bot. 25: 35-46.

Quezel, P. 1980. Biogéographie et écologie des coniféres sur le pourtour méditerranéen. -Actualités d'Ecologie Forestière, Sol, Flore, Faune, ed Pesson, Gauthier-Villars, Paris, pp. 205-255.

Raunkiaer, C. 1905. Types biologiques pour la géographie botanique. - Dan. Vidensk. Selsk. Forh. 5: 347-437.

Tarrega, R., Calvo, L. and Trabaud, L. 1992. Effect of high temperatures on seed germination of two woody Leguminosae. Vegetatio 102: 139-147.

Thanos, G. A. and Marcou, S. 1991. Post-fire regeneration in Pinus brutia forest ecosystems of Samos island (Greece): 6 years after. - Acta Oecol. 12: 633-642.

Thomson, K., Bakker, J. and Bekker, R. 1997. The soil seed banks of north west Europe: methodology, density and longevity. - Cambridge Univ. Press.

Trabaud, L. 1991. Le feu est-il un factor de changement pour les systèmes écologiques du bassin mediterranéenn. - Sécheresse 3: 163-174.

Trabaud, L. 1992. Influence du régime des feux sur les modifications à court terme et la stabilité à long terme de la flore d'une garrigue de Quercus coccifera. - Rev. Ecol. (Terre Vie) 47: 209-230.

Trabaud, L. and Campant, C. 1991. Difficulté de recolonisation naturelle du Pin de Salzmann Pinus nigra ssp. salzmannii (Dunal) Franco aprés incendie. - Biol. Conserv. 58: 329_ 343.

Trabaud, L. et al. 1997. Végétation épigée et banque de semences du sol: leur constitution à la stabilité cyclique des pinédes mixtes de Pinus halepensis et Pinus pinaster. - Can. J. Bot. 75: 1012-1021.

Tutin T. G. 1964-1980. Flora Europea. - Cambridge Univ. Press.

Valbuena, L., Tárrega, R. and Luis, E. 1994. Influence of heat on seed germination of Cistus laurifolius and Cistus ladanifer. Int. J. Wildland Fire 2: 15-20.

Van Der Pijl, L. 1969. Principles of dispersal of higher plants. Springler.

White, P. S. 1979. Pattern, process and natural disturbance in vegetation. - Bot. Rev. 45: 229-299. 